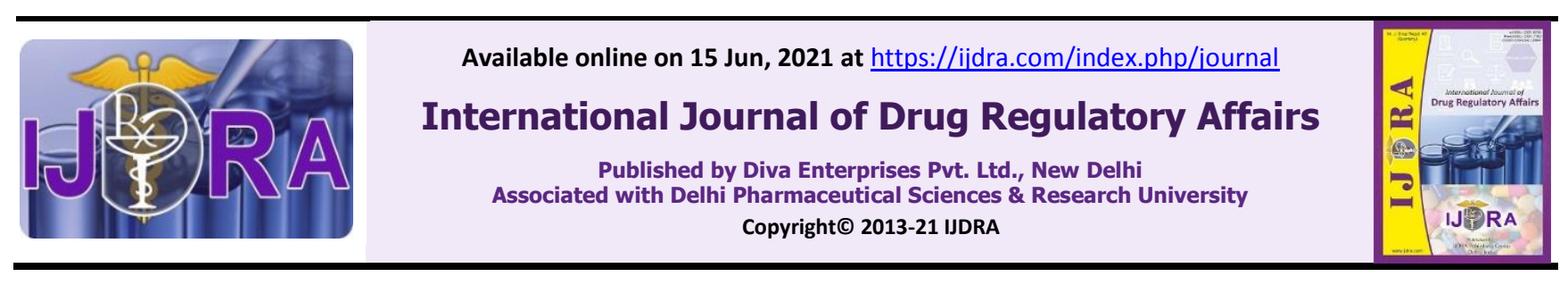

Review Article

Open Occess

\title{
Registration Process of Medical Devices in CIS Countries
}

\author{
Ayesha bi Shaik*, G.Ramakrishna \\ Department of Regulatory Affairs, Hindu College of Pharmacy, Amaravathi Road, Guntur - 522002, Andhra Pradesh, India.
}

\begin{abstract}
The Commonwealth of Independent States (CIS) is a region with constant, and often quite radical, changes in medical device regulations. This article summarizes the most significant new regulations in the largest CIS countries in order to provide a clearer picture of the regulatory requirements for medical devices in the region. The article also examines the new registration procedure for medical devices placed on the common market within the Eurasian Economic Union (EAEU) in accordance with the International Treaty within the EAEU. This Treaty defines the common principles and rules of circulation of medicinal products and medical devices.
\end{abstract}

Keywords: Commonwealth of Independent States (CIS), Eurasian Economic Union (EAEU), Medical Device Regulation, guidelines, harmonization, IVDs, registration

Article Info: Received 29 Apr. 2021; Review Completed 03 Jun. 2021; Accepted 08 Jun. 2021

Cite this article as:

Ayesha B Sk, G. Ramakrishna. Registration Process of Medical Devices in CIS Countries. Int J Drug Reg Affairs [Internet]. 2021 Jun 15 [cited 2021 Jun 15]; 9(2):35-42. Available from:

http://ijdra.com/index.php/journal/article/view/468

DOI: $10.22270 /$ ijdra.v9i2.468

*Corresponding author

\section{Introduction}

\section{CIS}

The Commonwealth of Independent States, which was framed after the separation of the previous Soviet Association, is a provincial association that attempts to co-ordinate exercises in the space of exchange, money, law and security. The CIS right now has nine Member States: Armenia, Azerbaijan, Belarus, Kazakhstan, Kyrgyzstan, Moldova, Russia, Tajikistan and Uzbekistan. It likewise has two Associated States: Ukraine and Turkmenistan. (1)

\section{EAEU}

The Eurasian Economic Union is a worldwide association for provincial monetary mix. A Settlement to build up the EAEU was endorsed on 29 May 2014 by the heads of Belarus, Kazakhstan also, Russia, and it came into power on 1 January 2015. (2) Afterward, Armenia and Kyrgyzstan joined the EAEU. As per its Treaty, Member States of the EAEU will set up a typical market of clinical items (therapeutic items and clinical gadgets) and structure a brought together way to deal with the guideline of clinical items circled inside the EAEU. (3) Endorsement of a typical market for clinical items in the EAEU was delayed from 1 January 2016 until April 2016. The Rules for the course of clinical gadgets in the EAEU are as of now expected to come into power during the third or final quarter of 2016.
2. Administrative bodies for clinical gadgets around there

- Armenia: There was no public arrangement on clinical gadgets until 1 January 2016. (4) Clinical gadgets will be constrained by the Logical Focal point of Drug and Medical Technology Aptitude after scholastic E Gabrielyan' (CJSC) (http://ww w.pharm.am/index.php/en/clinicalitems and-strategy registrationdepartment).

- Azerbaijan: There is no public arrangement on clinical devices. (5)

- Belarus: Medical gadgets are constrained by the Community for Examinations and Tests in Health Administration (http://www.rceth.by/en). The rundown of archives needed for enlistment, what's more, models, might be found at http://www.rceth.by/ru/Documents /Med/.

- Georgia: There is no public strategy on clinical devices. (6)

- Kazakhstan: Medical gadgets are constrained by the National Center for Medicines, Medical Gadgets and Medical Equipment Expertise (http://www.dari.kz/ classification/MT_saraptau).

- Kyrgyzstan: The Department for Medical Care and Clinical Equipment of the Ministry of Health 
(http://www.pharm.kg/ru/enrollment/) is liable for supervising clinical gadget controls.

- Moldova: The administrative expert for clinical gadgets is the Agency of Prescriptions and Medical Devices (http://www.amed.md/?go=page\&p=152).

- Russia: Roszdravnadzor (http://www.roszdravnadzor.ru/medproducts/enroll ment) is the association liable for clinical gadgets in Russia.

- Tajikistan: Medical gadget guideline is the duty of the Department for State Oversight of Pharmaceutical Activities

(http://www.pharmnadzor.tj/service_resolution.html)

- Turkmenistan: Medical gadgets are constrained by the Ministry of Health and Medical Industry of Turkmenistan (http://www.saglykhm.gov.tm/) what's more, are approved by the Ministry. On 12 January 2016, another Law of Turkmenistan about Medication Provision (in Russian) was distributed and may be found at:

http://turkmenistan.gov.tm/?id=10253.

- Uzbekistan: The General Administration of Quality Control of Medicines and Medical Hardware inside the Ministry of Health (http://www.uzpharmcontrol.uz/medizdeliya) is the association liable for clinical gadgets.

- Ukraine: Medical gadgets are constrained by the Service of Health (http://www.moz.gov.ua/ua/ gateway/mtip progress/) and the State Center for Mastery of the Ministry of Health (http://www.dec.gov.ua/index.php/ua/). Subtleties of the enrollment prerequisites for clinical gadgets might be found at:

http://www.diklz.gov.ua/control/principle/uk/distrib ute/article/533686.

\section{Late administrative changes in Ukraine}

In Ukraine, the arrangement of state enrollment of clinical gadgets has been supplanted by public congruity evaluation to Technical Regulations. (7) The Ukrainian Technical Regulations depend on the European Directives 93/42/EEC, 98/79/EC and 90/385/EEC. Since 1 July 2015, all clinical gadgets that enter the Ukrainian market should go through public congruity evaluation to the Technical Regulations (Pronouncements of the Cabinet of Ministers of Ukraine No 753 for clinical gadgets, No 754 for in vitro diagnostics (IVDs), and No 755 for dynamic implantable clinical gadgets).

The class of a clinical gadget decides regardless of whether the enrollment interaction should include an approved (told) body. Self-revelation is workable for:

- Class I (non-clean, non-estimating) clinical gadgets;

Table 1. Overview of the registration process for medical devices in Uzbekistan

\begin{tabular}{l|l|l|l}
\hline Step & \multicolumn{1}{|c|}{ Who? } & \multicolumn{1}{c}{ What? } & \multicolumn{1}{c}{ How long? } \\
\hline 1 & Applicant & Prepares documents and test samples & Not fixed \\
\hline
\end{tabular}

Analysers, reagents and other IVD items, which are excluded from the rundowns $\mathrm{A}$ or $\mathrm{B}$ of the Specialized Regulation for IVDs (Decree of the Bureau of Ministers of Ukraine No 754). Similarity appraisal including an approved body is needed for:

- Class I (clean or estimating) clinical gadgets and all clinical gadgets of Classes IIa, IIb, III;

- Self-testing IVDs, and IVD reagents, adjustment also, control materials contained in records $\mathrm{A}$ or B;

- All dynamic implantable clinical gadgets. Similarity evaluation including an approved body might be performed it is possible that (I) through Center CIS district (C) Journal of Medical Device Regulation - May 201615 appraisal of the documentation and an investigation of the assembling site, which will result in a testament being allowed for a very long time, or (ii) by evaluating each clump, which will result in a authentication being given for every shipment.

- A portion of the other Ukrainian-explicit clinical gadget necessities to know about are as per the following:

- Documentary master survey, nearby fabricating investigations and testing of tests of clinical gadgets are performed by public approved bodies (similar to European Notified Bodies).

- Assignment of an Authorized Representative in Ukraine by an unfamiliar producer has become compulsory under the new guidelines.

- Another prerequisite for a clinical gadget's bundle marking and directions for use has happen. This requires the consideration of the public congruity mark, just as the name and address of the Authorized Agent in Ukraine. On the off chance that an approved body was associated with the similarity appraisal strategy, it is important to incorporate its distinguishing proof number close to the public similarity mark.

- Information on the name and text of the directions for utilize should be given in the Ukrainian language, despite the fact that it might furthermore be converted into different dialects. Ongoing administrative changes in Uzbekistan

Following ongoing administrative changes, the enrollment system for clinical gadgets in Uzbekistan is presently equivalent to that for therapeutic products. (8) The enrollment system normally takes around 180 working days, and a revision to an existing enrollment regularly takes about 90 working days. An enrollment authentication is legitimate for a very long time. Table 1 sums up the enrollment measure in Uzbekistan. 


\begin{tabular}{|c|c|c|c|}
\hline 2 & $\begin{array}{l}\text { Registration Department } \\
\text { of the Ministry of Health } \\
(\mathrm{MoH})\end{array}$ & $\begin{array}{l}\text { Accepts application, documents and test } \\
\text { samples for: } \\
\text { - } \text { registration; } \\
\text { - renewal (three months before expiry } \\
\text { date); } \\
\text { - amendment; } \\
\text { - initial expert review. }\end{array}$ & 5 working days \\
\hline 3 & $\begin{array}{l}\text { Registration Department } \\
\text { of the } \mathrm{MoH}\end{array}$ & $\begin{array}{l}\text { Prepares contract and invoice for state } \\
\text { expert review. } \\
\text { - Sends documents for state expert review. }\end{array}$ & $\begin{array}{l}1 \text { working day after initial } \\
\text { expert review } \\
\text { - } 1 \text { working day after payment } \\
\text { received }\end{array}$ \\
\hline \multirow{7}{*}{4} & $\begin{array}{l}\text { Laboratories of the Center } \\
\text { of Expertise }\end{array}$ & $\begin{array}{l}\text { Performs laboratory tests and sends } \\
\text { conclusions to other departments. }\end{array}$ & $\begin{array}{l}\text { - For initial registration, less } \\
\text { than } 60 \text { working days } \\
\text { - For renewal or amendment of } \\
\text { an existing registration, less } \\
\text { than } 30 \text { working days }\end{array}$ \\
\hline & Pharmacology committee & \multirow{3}{*}{$\begin{array}{l}\text { Expert review of documents, comparison } \\
\text { with results of tests from state laboratory. }\end{array}$} & \multirow{6}{*}{ Less than 85 working days } \\
\hline & $\begin{array}{l}\text { Pharmacopoeia } \\
\text { committee }\end{array}$ & & \\
\hline & $\begin{array}{l}\text { New medical technique } \\
\text { committee }\end{array}$ & & \\
\hline & $\begin{array}{l}\text { Committee on control of } \\
\text { narcotic drugs }\end{array}$ & $\begin{array}{l}\text { Expert review of documents (if narcotic } \\
\text { drug, or psychotropic substances and } \\
\text { precursor chemicals are part of the drug). }\end{array}$ & \\
\hline & Pharma-inspection & Manufacturing site audit (if necessary). & \\
\hline & $\begin{array}{l}\text { Department for the } \\
\text { Coordination of the } \\
\text { Implementation of } \\
\text { International Standards in } \\
\text { the Pharmaceutical } \\
\text { Industry }\end{array}$ & $\begin{array}{l}\text { Preparation of conclusions on compliance of } \\
\text { the company to international standards (if } \\
\text { necessary). }\end{array}$ & \\
\hline \multirow{3}{*}{5} & Pharmacology committee & \multirow{3}{*}{$\begin{array}{l}\text { Preparation of conclusions and discussion } \\
\text { during Expert Council. }\end{array}$} & \multirow{3}{*}{ Less than 20 working days } \\
\hline & $\begin{array}{l}\text { Pharmacopoeia } \\
\text { committee }\end{array}$ & & \\
\hline & $\begin{array}{l}\text { New medical technique } \\
\text { committee }\end{array}$ & & \\
\hline \multirow[b]{2}{*}{6} & Expert Council & Decision to approve or reject a registration. & Less than 6 working days \\
\hline & $\begin{array}{l}\text { General Administration of } \\
\text { the } \mathrm{MoH}\end{array}$ & Issues order to register or reject. & 1 working day \\
\hline 7 & $\begin{array}{l}\text { Registration Department } \\
\text { of the } \mathrm{MoH}\end{array}$ & Issues and sends registration certificate. & 1 working day \\
\hline
\end{tabular}

Additional time: 45 days to answer a deficiency letter; 45 days to provide test samples and programme of clinical studies agreed with clinical site.

\section{Ongoing administrative changes in the EAEU}

New guidelines for the enrollment of clinical gadgets in the EAEU are required to be executed in the third or then again final quarter of 2016. Provision 11 of the Agreement on basic standards and rules for the flow of clinical gadgets in the EAEU presents a momentary period until 31 December 2021, during which time the enlistment of clinical gadgets might be performed as indicated by the public guidelines of the Member States (Armenia, Belarus, Kazakhstan, Kyrgyzstan, Russia) or as per the new fit enrollment technique of the EAEU. (9) Current (neighborhood), limitless enrollment authentications for clinical gadgets will stay legitimate until 31 December 2021 at the latest. (9)

\section{Rundown of the new EAEU enrollment system}

\section{Stage I: Preparation of reports}

a. A primer meeting is embraced with a specialist association (approved body), if vital.

b. Testing of the clinical gadget is done in an affirmed lab to assess the gadget's specialized qualities, toxicological qualities, kind of gadget (if necessary), and natural movement. 
c. Clinical preliminaries are directed for another clinical gadget. Clinical information from past clinical preliminaries ought to be remembered for the enrollment dossier.

d. The Reference Member State and Recognition States are chosen. The Reference Member State ought to be picked cautiously as it will play out the master survey. Determination of Recognition States additionally requires thought as an expense is charged per State for enlistment. Acknowledgment States will be recorded in the enlistment testament.

e. Records are ready for enlistment. The application and enlistment dossier are shipped off the enlistment association of the Reference Part State, alongside an ensured interpretation in Russian.

\section{Stage II: Registration measure}

a. Formal checking of the enlistment dossier takes 5 working days. In the event that the dossier is finished, the enlistment technique is started (3 working days). In the event that there is missing data, the candidate has 30 working days in which to react to the insufficiency letter.

b. A specialist audit of the gadget's quality, security what's more, viability is performed. This incorporates:

- Investigation of reports and materials to decide the security, viability and nature of the clinical gadget, including consumables also, extras;

- Examination of principles utilized;

- Examination of conventions for specialized tests and natural activity to guarantee fulfillment and guarantee the fitness of the research facilities that played out the tests;

- Acknowledgment of the test outcomes;

- Investigation of the report from the assembling site review (the review happens during the master survey stage (with the clock halted) be that as it may, before an end is reached and can require up to 90 working days);

- Examination and assessment of clinical information for consistence with the rules for clinical preliminaries, fulfillment, legitimacy of the outcomes, correlation of the clinical information with existing, undifferentiated from items and acknowledgment of the results;

- Examination of the dangers;

- Assessment of the propriety of the chosen hazard class and classification for the arrangement and classification frameworks, separately;

- Investigation of the wellbeing and viability of drugs that are important for the clinical gadget, their impact on usefulness, and their similarity with the clinical gadget (the drugs should be enlisted in their own ideal for use in the assembling nation and in the EAEU);

- Examination of the natural security of the clinical gadget dependent on the examinations of utilized materials of creature and human starting point, data about givers, determination of the materials, preparing, capacity, tests, approval of testing techniques and dealing with of tissues, cells, societies of microorganisms also, infections;

- Examination of the sanitization interaction, with data supporting the technique for cleansing, just as proposed techniques for quality control and for estimating the grouping of any excess disinfection specialists on account of compound sanitization;

- Examination of the legitimacy of any product utilized;

- Investigation of the soundness report and the legitimacy of the pronounced stockpiling conditions;

- Investigation of data on unfriendly occasions and impacts and withdrawals from the market related with the clinical gadget's utilization;

- Investigation of the candidate's assertion on consistence with the necessities for wellbeing what's more, adequacy;

- Examination of the nature of the bundling;

- Assessment of the directions for use and the client manual;

- Assessment of names and the bundling format.

For another enlistment this progression takes 60 working days. For an alteration to a current enlistment, this requires 30 working days. Assuming more data is required, the candidate has 60 working days in which to react to the inadequacy letter. When the master audit has been finished, either the application will be dismissed or an Expert Conclusion will be given (5 working days).

c. Assembling site reviews are led for Class 2a (clean), $2 \mathrm{~b}$ and 3 clinical gadgets and IVDs. This piece of the cycle takes 90 working days. This happens during the master audit stage (with the clock halted) however before an end is reached.

d. The exactness of the interpretations of the guidelines for use and item marking into the State dialects of the EAEU should likewise be confirmed. This requires 30 working days. This stage happens after the Reference Member State has distributed the master end (for example after a positive choice). The Recognition States have 30 days to send their remarks or potentially complaints, and to confirm the interpretation of the directions for use and item naming into their State dialects.

e. A choice on the endorsement or dismissal of the enlistment application will be given inside 10 working days.

f. The picked Recognition Member States at that point have 15 working days to remark on the enlistment choice. In the event that no remarks are gotten during this period, the enrollment choice will be considered acknowledged. The enlistment association of the Reference Part State will give the enrollment authentication. Enrollment authentications are substantial inconclusively in every one of the Recognition Member States picked by the candidate (as recorded on the enlistment testament).

In the event that a producer chooses to enroll a clinical gadget in another country that was not recorded 
as an Acknowledgment Member State at first, or in another country that joined the EAEU later, the producer or on the other hand neighborhood Authorized Representative should send the application to the enrollment office of the Reference Member State. The Expert Conclusion should be acknowledged by the extra Recognition Part State(s) and afterward the Reference Member State will give another enrollment authentication. Unfamiliar clinical gadget organizations should have an affirmed Quality Management System set up and give affirmation that the clinical gadget is enrolled in its nation of root.

\section{Variations to a registration dossier}

Variations to an existing registration are handled by the Reference Member State. The Reference Member State publishes the variation application and supporting documents on the EAEU's internal information system. The relevant Recognition Member States then have 30 working days to provide comments.

Table 2 lists the types of variations that may be made to a medical device on the market in the EAEU without the need to submit a new registration

Table 2. Variations that may be made to an existing registration in the EAEU

\begin{tabular}{|c|c|}
\hline \multicolumn{2}{|c|}{ Appendix 6 to the current version of the guidelines for the EAEU (10) } \\
\hline Type of variation & Required documents \\
\hline $\begin{array}{l}\text { Information about the } \\
\text { applicant, including } \\
\text { information on } \\
\text { reorganization of the } \\
\text { legal entity and/or its } \\
\text { name } \\
\text { Such a change must } \\
\text { not cause a change } \\
\text { (including an } \\
\text { improvement) in the } \\
\text { properties and } \\
\text { characteristics of the } \\
\text { medical device that } \\
\text { could affect its } \\
\text { quality, efficacy or } \\
\text { safety. The change } \\
\text { must not affect the } \\
\text { functional application } \\
\text { and/or mode of } \\
\text { operation of the } \\
\text { medical device. }\end{array}$ & $\begin{array}{l}\text { - Copy of the document confirming the power of the Authorized Representative to } \\
\text { represent the manufacturer. } \\
\text { - Number of the registration certificate. } \\
\text { - Documentation to confirm the variation(s). } \\
\text { - Table of contents. }\end{array}$ \\
\hline $\begin{array}{l}\text { Name of the medical } \\
\text { device }\end{array}$ & $\begin{array}{l}\text { - Application to make the variation(s). } \\
\text { Documents confirming the registration of the medical device in the country of origin } \\
\text { (e.g. a Declaration of Conformity, a registration certificate, a Certificate of Free Sale, a } \\
\text { Certificate for Export) with the relevant change(s) and a certified copy translated into } \\
\text { Russian. } \\
\text { - Copy of the registration certificate. } \\
\text { - Letter from the manufacturer explaining the need for the name change, and that the } \\
\text { functional and technical characteristics of the medical device are unaffected. } \\
\text { - Drafts of the instructions for use (user manual) for the medical Device. } \\
\text { - Layout of the label. } \\
\text { - Document specifying the requirements for the technical characteristics of the medical } \\
\text { device, which corresponds to the medical device under its new name. } \\
\text { - Operational documents of the manufacturer, including the revised instructions for use } \\
\text { and user manual. } \\
\text { - Photo of the medical device with its accessories (no smaller than } 18 \mathrm{~cm} \mathrm{x} 24 \mathrm{~cm} \text { ). } \\
\text { - Table of contents. }\end{array}$ \\
\hline
\end{tabular}




\begin{tabular}{|c|c|}
\hline $\begin{array}{l}\text { Accessories and } \\
\text { consumables } \\
\text { Any change must } \\
\text { have no effect on the } \\
\text { functional } \\
\text { characteristics of the } \\
\text { medical device. }\end{array}$ & $\begin{array}{l}\text { - Application to make the variation(s). } \\
\text { - Copy of the registration certificate. } \\
\text { medical device and stating the new list of accessories. The letter must also confirm the } \\
\text { absence of an effect on the functional and technical characteristics of the medical } \\
\text { device. } \\
\text { - Drafts of the instructions for use and the user manual in the relevant State and Russian } \\
\text { languages. } \\
\text { - Updated specification for the accessories and consumables. } \\
\text { - Table of contents. } \\
\text { - If an accessory is a medical device in its own right, a sample is required for analysis } \\
\text { and relevant regulatory documentation should be provided. }\end{array}$ \\
\hline $\begin{array}{l}\text { Indications } \\
\text { (contraindications) } \\
\text { for the application of } \\
\text { the medical device, } \\
\text { area of application of } \\
\text { the medical device, } \\
\text { side effects The } \\
\text { quality and safety of } \\
\text { the medical device } \\
\text { must remain } \\
\text { unchanged and be } \\
\text { confirmed by data } \\
\text { from tests. }\end{array}$ & $\begin{array}{l}\text { - Application to make the variation(s). } \\
\text { - Copy of the registration certificate. } \\
\text { - Letter from the manufacturer explaining the need to change the indications for use. } \\
\text { - Samples of the new instructions for use. } \\
\text { - Copy of the previously-approved instructions for use. } \\
\text { Full colour layout of the package, label and sticker (if available) on CD in JPEG } \\
\text { - Results of clinical (medical) trials, reflecting the variation(s). } \\
\text { - Table of contents. }\end{array}$ \\
\hline $\begin{array}{l}\text { Manufacturer } \\
\text { There may be no } \\
\text { changes in the } \\
\text { production process or } \\
\text { specifications, } \\
\text { including method of } \\
\text { testing. }\end{array}$ & $\begin{array}{l}\text { - Application to make the variation(s). } \\
\text { - Documents confirming the registration of the medical device in the country of origin } \\
\text { (e.g. a Declaration of Conformity, a registration certificate, a Certificate of Free Sale, a } \\
\text { Certificate for Export) with the relevant change(s) and a certified copy translated into } \\
\text { Russian. } \\
\text { - Document confirming the variation(s), including the date, and an authentic translation } \\
\text { into Russian. } \\
\text { - Document confirming compliance of production conditions to national and/or } \\
\text { international standards (e.g. Good Manufacturing Practice, EN ISO standards) with an } \\
\text { authentic, notarized translation into Russian. } \\
\text { - Document confirming compliance of the medical device to national and international } \\
\text { standards, and its potential risk class (Declaration of Conformity), with an authentic, } \\
\text { notarized translation into Russian. } \\
\text { - Copy of the registration certificate. } \\
\text { - Letter from the manufacturer confirming that the production process and the quality } \\
\text { and safety of the medical device remain unchanged, with a statement of the date of } \\
\text { variation(s). } \\
\text { - Drafts of the instructions for use (the user manual). } \\
\text { - Layout of the label. }\end{array}$ \\
\hline $\begin{array}{l}\text { Specification of the } \\
\text { manufacturer or } \\
\text { technical conditions } \\
\text { (upon availability) } \\
\text { and/ or operational } \\
\text { documents } \\
\text { No changes may be } \\
\text { made to the } \\
\text { production process or } \\
\text { specification, } \\
\text { including testing } \\
\text { methods. }\end{array}$ & $\begin{array}{l}\text { - Application to make the variation(s). } \\
\text { - Copy of the registration certificate. } \\
\text { - Letter from the manufacturer explaining the need to make the change(s). } \\
\text { - If necessary, stability data for the medical device for at least three batches plus a report } \\
\text { justifying the shelf-life. } \\
\text { - Samples of the instructions for use and user manual. } \\
\text { - Full colour layout of the package, label and sticker (if necessary). } \\
\text { - Regulatory documents updated with the variation(s), including details of the quality of } \\
\text { the end product, the certificate of analysis, and the method of quality control of the end } \\
\text { product, with an authentic, notarized translation into Russian. } \\
\text { - Protocol of technical tests/tests to evaluate biological action with the updated variation(s) } \\
\text { made to the regulatory documents (if necessary). }\end{array}$ \\
\hline
\end{tabular}




\section{Key achievements and proposals}

The enrollment technique for clinical gadgets in the EAEU is relied upon to become effective during the third or final quarter of 2016 with a progress period until 31 December 2021. Organizations ought to begin to design now for consistence with the new prerequisites and ought to likewise assess the related expenses. In Ukraine, the cutoff time for existing enlistment authentications to terminate has been expanded until 1 July 2017 by 'On Amending Resolutions of the Cabinet of Ministers of Ukraine', No 240 of 23 March 2016. (11) Conversations are additionally occurring on another lawful initiative (12) to guarantee the public Register holds data about clinical gadgets enlisted before July 2015, with enrollment data kept until in any event June 2020. All nearby enrollment declarations in the EAEU Part States will terminate on 31 December 2021. Organizations need to design new enrollments in any event nine months ahead of time and select the Reference Part State cautiously. It is the creators' feelings that master boards of trustees in various States may work in an unexpected way, despite the fact that it is hard to anticipate at Center - CIS area Table 2. Varieties that might be made to a current enlistment in the EAEU (proceeded) Addendum 6 to the current variant of the rules for the EAEU 10 Kind OF VARIATION Determination of the producer or specialized conditions (upon accessibility) and/ or then again operational records No progressions might be made to the creation interaction or determination, including testing techniques.

\section{Required documents}

- Document affirming consistence of creation conditions to public or potentially global guidelines (for example Great Assembling Practice, EN ISO principles) with a legitimate, notarized interpretation into Russian.

- Document affirming consistence of the clinical gadget to public and global norms, and its potential danger class (Revelation of Conformity), with a valid, notarized interpretation into Russian.

- Copy of the enrollment endorsement.

- Letter from the maker affirming that the creation measure and the quality and security of the clinical gadget remain unaltered, with an assertion of the date of variation(s).

- Drafts of the directions for use (the client manual).

- Layout of the name.

- Table of substance.

- Application to make the variation(s).

- Copy of the enlistment authentication.

- Letter from the producer disclosing the need to make the change(s).

- If essential, steadiness information for the clinical gadget for in any event three groups in addition to a report advocating the timeframe of realistic usability.

- Samples of the directions for use and client manual.

- Full shading design of the bundle, mark and sticker (if important).
- Regulatory reports refreshed with the variation(s), including subtleties of the nature of the final result, the endorsement of investigation, and the technique for quality control of the final result, with a credible, notarized interpretation into Russian.

- Protocol of specialized tests/tests to assess natural activity with the refreshed variation(s) made to the administrative reports (in the event that important).

- Table of substance. Additionally, for instance, in Armenia there is no actual framework for the enlistment of clinical gadgets at all for the occasion, so the interaction would unquestionably be diverse contrasted with Russia. It is too likely that the time taken for a maker site review will be longer if there are an inadequate number of specialists in a specific State. New marks will require to be appended to clinical gadgets by the cutoff time, as well.

\section{Conclusion}

The clinical gadget guidelines in the CIS locale change regularly. For instance, Russia presented a significant upgrade of its gadget guidelines in 2013, which came about in $47 \%$ of enrollments being denied that year. Presently, a totally new enrollment system inside the EAEU will before long be presented. Because of the way that new guidelines are presented regularly around there, the administrative demonstrations are regularly inadequately characterized and open to translation. Combined with the way that data accessible in English is exceptionally restricted and unfamiliar assembling organizations need to depend generally on data introduced by nearby merchants, the appropriate enlistment method for clinical gadgets can be hard to comprehend what's more, follow. Despite the fact that the new EAEU enrollment measure brings up numerous issues right now (for example how might it work practically speaking, when will it be conceivable to enlist in the EAEU, what clinical information will be thought of?) and obligatory fabricating site review necessities may significantly muddle the enrollment cycle, generally the new enrollment cycle ought to, in the future, be more basic and permit simpler (and presumably less expensive) admittance to a business opportunity for drugs and clinical gadgets with around 180 million individuals. Organizations are urged to follow the development of the EAEU, as the expansion of new Member States could carry with it new deals openings.

\section{Acknowledgements}

The author is very much thankful to International Journal of Drug Regulatory Affairs for publishing the article.

Financial Disclosure statement: The author received no specific funding for this work.

\section{Conflict of Interest}

The author declares that there is no conflict of interest regarding the publication of this article.

References 
1. Regulatory Affairs [Internet]. Pharmaguideline; 2019 Dec 29 [cited 2021 Jan 03]. Available from: https://www.pharmaguideline.com/2012/12/regulatoryaffa irs.html

2. Regulatory Affairs [Internet]. EUPATI; 2016 [cited 2021 Jan 04]. Available from: https://www.eupati.eu/glossary/regulatoryaffairs/

3. P. Praneeth, "Regulatory Affairs and its Role in Pharmaceutical Industry" SSRG International Journal of Pharmacy and Biomedical Engineering. 2016; 3(1):1-2. http://dx.doi.org/10.14445/23942576/IJPBE-V3I1P101

4. Gratisol. Regulatory Affairs - Interview Questions [Internet]. Gratisol; 2020 [cited 2021 Jan 07]. Available from:

http://gratisol.com/index.php/lifesciencestraining/regulatory-affairs

5. Commonwealth of Independent States [Internet]. Cisstat; 2019 [cited 2021 Jan 06]. Available from: http://www.cisstat.com/eng/cis.html

6. List of Globally identified Websites of Medicines Regulatory Authorities. World Health Organization [Internet]. WHO; 2012 [cited 2021 Jan 05]. Available from:

https://www.who.int/medicines/areas/quality_safety/ regulationlegislation/list_mra_websites_nov2012.pdf

7. List of Authority Websites - Tarius - Global Regulatory Requirements [Internet]. Tarius; 2018 [cited 2021 Jan 02]. Available from: http://www.tarius.com/?page_id=612

8. The Essential List of Regulatory Authorities in Asia [Internet]. RAPS; 2015 [cited 2021 Jan 04]. Available from:

https://www.raps.org/regulatory-

focus/newsarticles/2015/4/the-essential-list-of-regulatoryauthoritiesin-asia

9. ICH CTD M4: The Common Technical Document [Internet]. ICH [cited 2021 Jan 09]. Available from: https://www.ich.org/page/ctd

10. Common Technical Document-Pharma Dossiers-CTD Format [Internet]. Perfect dossier; 2020 [cited 2021 Jan 09]. Available from: http://www.perfectdossier.com/ctddossiers.html

11. Jordan, D. An overview of the Common Technical Document (CTD) regulatory dossier. Medical Writing. 2014; 23(2):101-105. http://dx.doi.org/10.1179/2047480614Z.000000000207

12. Badjatya J. Overview of Drug Registration Requirements For Pharmaceuticals In Emerging Market. JDDT [Internet]. 15Mar.2013 [cited 16Jun.2021];3(2). Available from:

http://jddtonline.info/index.php/jddt/article/view/466 